\title{
Low education, more frequent of seizure, more types of therapy, and generalized seizure type decreased quality of life among epileptic patients
}

\author{
Irawaty Hawari, Zakiah Syeban, Silvia F Lumempouw
}

\begin{abstract}
Abstrak
Bagi orang dengan penyakit kronis seperti epilepsi, kesembuhan kadang sulit dicapai dan pengobatan memakan waktu lama, sehingga kualitas hidup menjadi salah satu tujuan utama. Tujuan tulisan ini adalah untuk mendapatkan skor kualitas hidup penderita epilepsi serta faktor-faktor demografik dan medik yang mempengaruhi. Penelitian potong lintang menggunakan instrumen Quality of Life in Epilepsy (QOLIE)-31 untuk menilai kualitas hidup penderita epilepsi yang berobat jalan di Poliklinik Epilepsi RSCM. Sampel diambil secara konsekutif sejak Agustus 2005-Desember 2005. Dilakukan deskripsi demografi dan medik. QOLIE-31 terdiri dari komponen kekhawatiran akan serangan, kualitas secara umum, kesejahteraan emosional, energi/fatigue, fungsi kognitif, efek pengobatan, dan fungsi sosial. Dari 145 subjek, didapatkan skor total QOLIE-31 antara 28 - 95 (rerata = 67.6 ; standar deviasi $=14.55)$. Rendahnya skor total QOLIE berhubungan dengan pendidikan yang rendah, frekuensi serangan yang sering, penggunaan obat antiepilepsi (OAE) politerapi dan jenis serangan epilepsi umum. Penggunaan obat antiepilepsi politerapi merupakan faktor yang paling dominan terhadap rendahnya skor total QOLIE-31. Penelitian ini sesuai dengan penelitian sebelumnya di India, Georgia dan Korea Selatan. Di samping itu peneliti juga menemukan pendidikan sebagai faktor risiko terhadap total skor QOLIE-31. (Med J Indones 2007; 16:101-3)
\end{abstract}

\begin{abstract}
Persons with chronic disease such as epilepsy, where a cure is not attainable and therapy may be prolonged, quality of life (QoL) has come to be seen as an important goal. The objective of this study was to identify scores of quality of life (QoL related to clinical factors. A cross-sectional study using QOLIE-31 instrument to identify quality of life among ambulatory epileptic patients at Epileptic Clinic of Department of Neurology-Cipto Mangunkusumo Hospital. Samples were taken consecutively from August 2005 to December 2005. Several demographic data as well as clinical were collected. QOLIE-31 components consisted of seizure worry, overall quality of life, emotional well-being, energy/fatigue, cognitive function, medication effect and social function. We found among 145 subjects the total score of QOLIE-31 ranged from 28-95 (mean = 67.6; standard of deviation = 14.55). The total score of QOLIE-31was corelated with low education, more frequent of seizures, antiepileptic drug politherapy and type of generalized seizure. antiepileptic drug politherapy was the most dominant risk factor for lowering total score of QOLIE-31. Our finding was in accordance with previous studies in India, Georgia, South Korea. In additioin we found that education was also a risk factor for total score of QOLIE-31. (Med J Indones 2007; 16:101-3)
\end{abstract}

Keywords: epilepsy, quality of life, QOLIE-31, risk factors

Quality of life (QoL) in epilepsy has focused on the health related quality of life (HRQoL). Vickrey et al (1993) defined HRQoL as encompassing physical, mental and social functioning and well being, including how well an individual functions in daily living. 1,2

According to World Health Organization Quality of Life group (WHOQOL-group), quality of life is an

Department of Neurology, Faculty of Medicine University of Indonesia/Dr. Cipto Mangunkusumo General Hospital, Jakarta, Indonesia individual's perception of their position in life in the context of the culture and value systems in which they live and in relation to their goals, expectations, standards and concerns. It is a board ranging concept affected in a complex way by the person's physical health, psychological state, personal beliefs, social relationships and their relationship to salient features of their environment. ${ }^{3}$

The Quality of Life in Epilepsy (QOLIE-31) assessment has been used in many countries in Europe, America, Asia and Africa. For example, the mean score QoL in Moscow, Russia was 49.9 \pm 5.4 (242 subject) ${ }^{4}$ and in India was $68.0 \pm 15.8$ (112 subject) ${ }^{5}$ 
This research paper aim was to identify QoL scores, demographic and clinical factors related to epileptic patient's QoL.

\section{METHODS}

This was a cross-sectional study on ambulatory epileptic patients at Epileptic Clinic of Department of Neurology in Cipto Mangunkusumo Hospital. Samples were taken consecutively from August 2005 to December 2005.

The inclusion criterias were male or female of $18-60$ years old with minimum education level of junior high school, had been diagnosed with epilepsy and visited epileptic clinic for at least 1 year, taking an antiepileptic drug regularly and understand Indonesian language. The subjects were excluded if they had physical or mental limitations not allowing them to complete the Quality of Life in Epilepsy Inventory 31 (QOLIE-31) questionnaire. Subjects with psychiatric or neurological disorders that would impair judgment or impact quality of life (including mental retardation, stroke, brain tumor, cerebral palsy) or pregnant women were also excluded.

The demographic variables assessed by means of an ad hoc questionnaire were age, gender, education level and employment status. The clinical variables were age at first seizure (to classify patients as having early-onset epilepsy if the first seizure occurred before 20 years of age and late-onset epilepsy if the first seizure occurred after 20 years of age), duration of taking antiepileptic drug, frequencies of seizures in the last 12 months prior to enrollment and type of therapy. Type of seizures according to the Revised Clinical and Electroencephalographic Classification of epileptic Seizures (we divided into two categories: Partial seizures and generalized seizures).

Quality of life was measured with the QOLIE-31, which has been extensively tested for validity and reability. ${ }^{6}$ Patients completed the QOLIE-31 questionnaire by themselves and scored by us according to the scoring manual provided by Rand. The QOLIE-31 measures quality of life in seven domains (seizure worry, overall quality of life, emotional well-being, energy / fatigue, cognitive function, medication effect and social functioning). The score range was 0 to 100 and the lower score revealed a lower quality of life.

Statistical analysis was performed using the software package of STATA 6.0 software. Linear regression analysis was carried out with $95 \%$ confidence interval to identified related risk factor for QoL.

\section{RESULTS}

The eligible number of subjects was 147. One subject refused to participate in this study, and another one had incomplete data, leaving 145 subjects for this analysis. The subjects ranged aged 18 to 60 years; onset of epilepsy one to 36 years; duration of epilepsy one to 48 years.

Furthermore, the subjects: more female than male; most of frequency of seizure was less than 10 times seizures per year; more generalized seizure; most of them were taken single drug; and most subjects had graduated from senior high school; employed and unemployed subjects was almost similar number.

Table 1. Several demographic and clinical characteristic

\begin{tabular}{lc}
\hline & Mean \pm SD or n $(\%)$ \\
\hline Age & $31.41 \pm 9.78$ \\
Onset of epilepsy & $16.79 \pm 7.54$ \\
Duration of epilepsy & $14.56 \pm 9.40$ \\
Education (years) & $12.23 \pm 2.76$ \\
Gender & \\
Male & $63(43.4 \%)$ \\
Female & $82(56.6 \%)$ \\
Seizure frequency & \\
Free seizure & $38(26.2 \%)$ \\
$\leq 10 /$ year & $69(47.6 \%)$ \\
$\geq 10 /$ year & $38(26.2 \%)$ \\
Epilepsy & \\
Partial epilepsy & $52(35.9 \%)$ \\
Generalized epilepsy & $93(64.1 \%)$ \\
Anti epileptic drug & \\
Single drug & $124(85.5 \%)$ \\
Two drugs & $19(13.1 \%)$ \\
Three drugs & $2(1.4 \%)$ \\
Employment & \\
Employed & $68(46.9 \%)$ \\
Unemployed & $60(41.4 \%)$ \\
Student & $17(11.7 \%)$ \\
\hline & \\
\hline & \\
\hline & \\
\hline & \\
\hline & \\
\hline
\end{tabular}

Total score of quality of life ranged from 28 to 95 . 
Our final multivariate analysis result (Table 2) shows that level of education increased risk for quality of life. However, type of seizure, frequency of seizure, type of therapy decreased risk for quality of life. If compared to those who had lower education (junior high school), the subject who had senior high school or college/university education to be better quality of life.

The most risk factor which lowering quality of life was the number of drugs taken by the subjects. Those who had two or three drugs than one drug had lower quality of life.

Table 2. The relationship between several dominant factors and the risk of quality of life

\begin{tabular}{lcrc}
\hline & Coefficient & \multicolumn{1}{c}{$95 \%$ CI } & $\mathrm{p}$ \\
\hline Education (years) & 0.88 & $0.07 ; 1.69$ & 0.033 \\
Type of seizure & -3.99 & $-7.27 ;-0.72$ & 0.017 \\
Freq. of seizure & -4.15 & $-7.23 ;-1.07$ & 0.009 \\
Type of therapy & -7.89 & $-13.49 ;-2.30$ & 0.006 \\
\hline
\end{tabular}

\section{DISCUSSION}

There are several limitations that must be considered in the interpretation of our finding among others: the number of subject was limited came from the national referral hospital in Indonesia. Therefore the finding was not reflected in Indonesian general epileptic cases. However, our finding was the first published in Indonesia.

In this study, the total score of quality of life ranged from 28-95. In our study, low education level, more frequent of seizures, generalized seizure type and antiepileptic drug polytherapy were the factors which most dominantly associated to lowering quality of life. We did not find any association with gender, occupation status, onset and duration of epilepsy.

The fact that education was one of the dominant predictors of low HRQL in this study was in accordance with the results of previous studies in Korea and Georgia. ${ }^{7,8}$ We could not find any study on patient populations from the western world that assessed the role of education in determining HRQL. In western societies, better educated people are employed and have higher income; therefore they have most likely focused on employment only. This situation may be different in Indonesia, where income levels of many people with high educational attainments were disrupted (mainly because of macroeconomic changes), so the educational level seems to be more significant of HRQL in people with epilepsy.
High frequency of seizure and generalized seizure type had a significant influence on lower quality of life among our patients was in accordance with the results of previous studies in India, Georgia and Mexico. ${ }^{5,8,9}$ Antiepileptic drug polytherapy was also one of the significant predictive factors for lowering quality of life. This result was in agreement with that of Sanjeev et al. ${ }^{5}$

In conclusion, low education, more frequent of seizures, antiepileptic drug polytherapy, and generalized seizure type were associated with lower QOLIE-31 scores.

\section{Acknowledgment}

The authors would like to thank all patients who participate with this study; the Epileptic Clinic of Department of Neurology - Cipto Mangunkusumo Hospital for permission to access data. Lastly to Dr. Joedo Prihartono and Prof. Bastaman Basuki for technical assistance.

\section{REFERENCES}

1. Hermann B, Bishop M. Impact of epilepsy on quality of life in adults: a review. In: Baker GA, Jacoby A, editors. Quality of life in epilepsy. University of Liverpool, UK: Harwood Academic Publisher; 2000. p.103-15.

2. Jacoby A. Theoretical and methodological issues in measuring quality of life. In: Baker GA, Jacoby A, editors. Quality of life in epilepsy. Univ Liverpool, UK: Harwood Academic Publisher; 2000. p.43-51.

3. Suurmeijer TP, Reuvekamp MF. Aldenkamp BP. Social functioning, psychological functioning, and quality of life in epilepsy.Epilepsia. 42: 2001;1160-8.

4. Gusev EI, Guekht AB, Dzugaeva FK, Milchakova LE, Lokshina OB, Feygina AA et al. Quality of life in patients with epilepsy. Eur J Neurol. 2004;11 Suppl 2:228.

5. Sanjeev VT, Samuel K, Sudhakaran N, Sankara P. Frequent seizures and polytherapy can impair quality of life in person with epilepsy. Neurology India. 2005;53:46-50.

6. Cramer JA, Perrine K, Devinsky O, Comstock LB, Meador K, Hermann B. Development and cross-cultural translations of a 31-item quality of life in epilepsy inventory.Epilepsia. 1998;39:81-8.

7. Choi-Kwon S, Chung C, Kim H, Lee S, Yoon S, Kho H, et al. Factors affecting the quality of life in patients with epilepsy in Seoul, South Korea. Acta Neurologica Scandinavica. 2003;108(6):428-34.

8. Djibuti M, Shakarishvili R. Influence of clinical, demographic, and socioeconomic variables on quality of life in patients with epilepsy: findings from Georgian study. J Neurol Neurosurg Psychiatry. 2003;74:570-3.

9. Guevara IA, Peňa E, Corona T, Ayala LT, Meza LE, Gomez LM. Sleep disturbances, socioeconomic status, and seizure control as main predictors of quality of life in epilepsy. Epilepsy \& Behavior. 2005;7:481-5. 
